\title{
Flies on film
}

\section{ハ工の行動監視システム}

\author{
Lizzie Buchen
}

Nature Vol. 462(562-564)/ 3 December 2009

八工の行動解明に自動スクリーニング法を取り入れるユニークな 共同研究が行われている。今後、機械でヒトの行動を観察する方 法にも変革が訪れるかもしれない。

その映像には、ショウジョウバエの喧嘩が 映っていた。喧嘩はまるで大したことがな く、2 匹のショウジョウバエが何分の 1 秒 間か接触しただけに見えた。しかし再生 速度を 20 分の 1 に落とすと、鮮やかで豪 快なプロレス技が映し出された。生物学 者の David Anderson は、コンピューター で再生したこの粗い画質のモノクロビデオ を、「ハエのルチャリブレ（メキシカンスタ イルのプロレスリング)」とよんでいる。

1 匹の雄バエが後肢で立ち上がって、 隣のハ工の背中をつかむやいなや、後ろ に宙返りして相手を空中に放り投げる。こ の過程で、投げたハ工自身は2 回も宙返 りする。放り投げられたハ工は、なすすべ なく羽ばたきをしながら床に落ちて跳ね返 り、その後正しい姿勢に戻って離れる（こ のビデオは、go.nature.com/o8sRLs で 閲覧可。撮影は、ドイツのヴュルツブルク 大学の Martin Heisenberg)。こうした「投 げ技」は、Anderson がカリフォルニア工 科大学 (Caltech) で研究しているハエの 数十種類の行動様式の 1 つにすぎない。

「我々は自分たちの住む世界全体につ いて、全くわかっていないのです」と話す
のは、Anderson の共同研究者で、同じく Caltech に所属する Pietro Perona である。 彼は、比較的最近になって、ショウジョウ バエの世界に足を踏み入れた。これまで、 コンピューターを使った視覚研究を行っ ており、20 年間にわたってヒトの複雑な 行動様式を検知・解明できる装置の開発 を試みてきた。壮大な目標だが、彼は Anderson や行動神経科学者の Michael Dickinson という同志を思いがけなく得る ことができた。3 人は 2005 年ごろから、 ショウジョウバエの神経系の操作が容易に でき、攻撃や求愛といった複雑な社会行 動を自動的に探知・追跡できるツールを 作り出すために、共同研究を行っている。 彼らは、ハ工の行動の神経的基盤を解明 したいと考えているのだ。このことは、ヒ トの行動様式を解明することにつながる 可能性もある。

2009 年、共同研究チームは神経系の 容易な操作と自動的に社会行動の探知 · 追跡が可能な 2 つシステムを開発して 報告した ${ }^{1,2}$ 。Anderson は、現在それら を使って、行動を支配する遺伝子や神経 回路を解明するために、何千系統もの変
異ショウジョウバエをスクリーニングして いるところである。また、Dickinson は大 規模集団内でのハエの社会的動態を調べ ているが、これを実験室内で行うのはこれ までほぼ不可能だった。

「これは一筋縄ではいかない問題です」 と、カナダにあるトロント大学ミシサガ校 の神経遺伝学者Joel Levine はいう。彼 は2009年 11 月から、これらの新しい ソフトウェア・プログラムの 1 つである 「Ctrax」を用いている。「私はこれまで 長きにわたって、たくさんの人材を採用し て、この種のソフトウエアを作ろうとして きました。しかし誰一人として成功した者 はいませんでした」。

こうして開発されたプログラムは自由 に利用できるので、世界中のショウジョウ バエ研究者が新技術を使って、それぞれ 思いどおりの方向に研究を進め始めてい る。Perona も、ハ工を通じて、ヒトの行 動様式を解明できる機械装置の構築とい う自身の目標に少しずつ近づいている。

このようなツールは、ハエの行動研究と いう分野、なかでも裏方的な仕事をして いる学生や技官、ポスドクにとってありが 


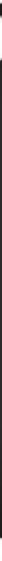

たい存在になるだろう。彼らはビデオ映像 をひとコマごとに見て、飛びかかりの数を すべて記録し、すべての追い回し行動の 時間を計り、羽による威嚇をすべて分類し、 そしてこれらを繰り返し行っているからだ。

「ビデオの前に座ってハエの行動を手 で記録していくのは、退屈でつまらない 作業ですからね」と、Caltech の教職員 用レストランでAnderson は、Perona と Dickinson の 2 人と昼食をとりながら語つ た。しかも、単に時間の節約になるだけ ではないのだ、とPerona が付け加える。 回数を正確に数えるといっても、ハエの 観察には主観が入る。「クリップボードとス トップウォッチを使う方法をとっているとし ましょう。Caltechには実際に、それをやっ ているポスドクが 1 人いますし、ノルウエー にも同様なポスドクが 1 人います」。しか し、もし観察結果が一致しなければ、答 えを得ることは不可能に近くなるのだ。な ぜなら「この 2 人のポスドクがどこかに職 を得て研究室を去ったら、異なる見解が 平行線をたどった状態で止まってしまいま す。基盤になるものがないため、その見 解が事実かどうかを決して確認できなくな るからです」。

\section{すべて監視している}

Perona は、ヒトの動きを観察して、その 行動や意図を理解できる機械の開発を試 みてきた。こうした能力を備えた機械は、 さまざまな方面に応用できる。例としては、
機械の操縦者が眠気でうとうとしたときに 警告を発する作業監視カメラや、空港で 不審な挙動を察知して知らせる防犯カメ ラなどがある。

こうしたシステムを構築するには、機 械視覚という分野の研究者が、ごく一般 的なラベルデータのコンピューター言語を 使ってプログラミングする。これにより、 例えば、交差点に進入する歩行者を数千 例解析し、新規の状況での歩行者の行動 を識別できるアルゴリズムを作成すること ができる。

しかし、「不審」もしくは「危険」な挙 動を識別することが目標である場合、単純 で特異的な行動を対象としていてはあまり 役に立たない。Peronaはこの問題に対 処するため、行動を複数の構成要素に分 解することを試みている。

例えば、ワインをグラスに注ぐという動 作には、瓶を手でつかんで持ち上げ、グ ラスのところまで持って来て、瓶の口をグ ラスに向けて下げた後、また上げるところ まで含まれる。Perona はこうした動作の 構成要素を「moveme」と名付けた ${ }^{3}$ 。 moveme は彼のいう「行動の階層構造」 の基本である。複数の moveme が組み 合わさって、ワインを注ぐなどの 1 つの action になる。そして、夕食をとるなど、 時間のかかる action が、 activity といえる。 しかし、彼によれば、こうした理論を検証 するには、コンピューターで画像処理でき るようにラベル付けしたビデオ映像のセッ
トが多数必要だというが、こうしたビデオ を用意するのは簡単なことではない。

「検証に必要な十分な量のデータは、ま ず得られません」と Peronaはいい、指 を折って数えながらその理由を並べた。ま ず、本人の同意なしに録画するのは違法 であり、また承諾を得るのも難しい。そし て、たとえ承諾を得られたとしても、自然 体の行動を撮影することは難しいのだとい う。「しかもヒトの観察は退屈です。パブで 喧嘩が 1 つ見られるまで、どれくらい時間 がかかると思いますか」と Perona はいう。

Perona は、生命科学研究から 1 つの ヒントを見つけた。「生物学者は統合失調 症のようなやっかいな問題に対処すると き、どうしますか」と彼は問いかけてきた。 「彼らは、モデル生物を使うのですよ。モ デル生物を使えば、体を傷つけてしまう侵 襲的な実験も行うことができ、さくつと解 答を得ることができるのです」。

彼は2、3 年前から、Caltech の同僚た ちに、彼らが研究に使っているモデル生物 について尋ね始めた。ちょつとおもしろくて、 しかしあまり複雑でない行動をするモデル 生物を探したのである。一方 Andersonは、 そのころちょうど長期研究休暇から戻って きたところだった。出向先では、ショウジョ ウバエがどのくらい動き回っているかを、 既製ツールを用いて測定していた。

「そのツールは、まあ機能はしていま したが、洗練されたものとはいえませ んでしたね」とAndersonは振り返る。 


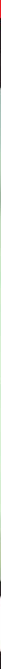

プロの戦士 : ショウジョウバエの行動は大方の予想よりもずっと複雑だ。

Dickinson は、Anderson 自身が何か作り 出すべきだと提案した。そこでAnderson は、ショウジョウバエの複雑な行動様式 を記述することをPeronaにもちかけた。 Perona は非常に興味をそそられた。「私 は当時、ハエというのは空中をブンブン 飛び回ることぐらいしかしていないと思っ ていたのです」と彼は話す。

\section{大志を抱く}

Andersonは、攻撃や求愛に際して現れ る特定の行動様式を自動的に検出できる プログラムが欲しいと考えた。羽による威 嚇、追い回し、レスリング、交尾などを自 動的に数え、時間を測るのである。彼が 求めていたのは、ハエのペアを同時に多 数行動させるのを可能にすることと、ひと つひとつの行動がいつどこで、どんな順 序で現れるかを記録し、そのデー夕を吐き 出してくれる機械だった。

研究歴のほとんどを空気力学と生体力 学に費やしてきた Dickinson は、数十匹 から数百匹の集団内で八エたちがどのよ うに振る舞うかを解明したいと思った。こ れを実行するためには、ハエ 1 匹ごとの 動きを追跡し記録したり、長時間にわたっ て同一個体のハ工を追いかけたりする必 要があると考えられた。これは、誰もやっ たことがなかった。当時、八工を追跡でき るプログラムは 2、3 あったが、それらに はいわゆるオクルージョン問題（視点が変 わると、同じ対象物でもそれぞれの視点か

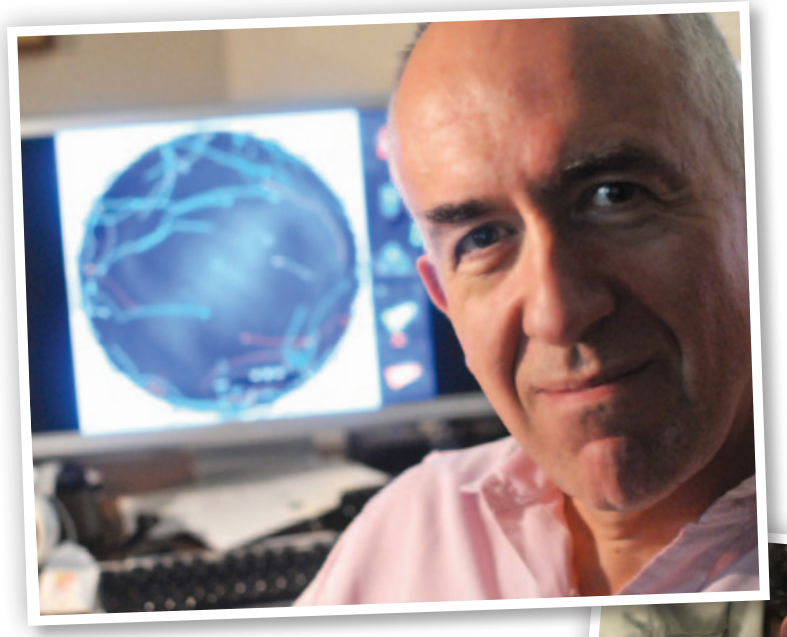

Pietro Perona は機械視覚シ ステムを使ってハエを追跡し ている。
ハエの観 察: Michael Dickinson (左) と David Anderson はコンピュー ターの視覚プログラムを 使ってハエの行動様式の 解明を進めている。 
ら見えている部分が異なること）があった。 だからもし、2 匹のハエが接触したり同じ ピクセル内に入ったりしてしまうと、実験 者は八エたちの分離処理法を機械に手で 入力しないとならなくなってしまうのだ。

Anderson と Dickinson のどちらの要 望も、Peronaにとって難しい注文だっ た。「でも、それが共同研究のすばらしい 点なんですよ。生物学者がまずほとんど 不可能だろうと思っていることが、Pietro (Perona) のような別分野の研究者にとっ ては、実現可能な領域だったりするのです」 とAndersonは話す。

Anderson のいう特殊な行動検知装置 とDickinson の望む探査・追跡装置に は、さまざまなソフトウエアが必要だった が、そうした課題は意外と簡単だったよう である。Perona は Kristin Branson とい うポスドクを Dickinson と共有しており、 Anderson とは Heiko Dankert という別 のポスドクを共有していた。Peronaは、 当初、それぞれのプログラム作成に数か 月程度かかると見積もっていた。「しかし ご覧のように、完成までに 3 年かかって しまいました。まあ、問題はありませんで したけどね」とPerona はいう。作業時 間の多くは、システムを生物学者に理解 できるものにすることと、他人の管理下で
も確実に機能できるよう安定かつ堅固な ものにすることに費やされた。Dickinson は、これを自動車組み立て工程にたとえて、 「フェンダーや車体を取り付ける作業」と よんでいる。

一方、Dickinsonは解析のために、 Branson が開発したソフトウエアである Ctrax 利用できる環境を作り出そうと、 いろいろ工作した。できあがったものは、 サッカーボール 1 個が入るくらい大きい円 形アリーナで、周囲には 8 個のハロゲン ライトが取り付けられた。

内部には、羽を切られた 50 匹ものショ ウジョウバエが歩き回っている。羽を切っ たのは、飛び上がって追跡システムが混乱 してしまわないためである。アリーナ中央 の上には 1 個のカメラが直接吊り下がって おり、ハエの動きをとらえて、そのデータ をそばのコンピューターへ伝送する。それ ぞれのハエがアリーナ内を探検すると、モ ニター上には細くて鮮やかな色の軌跡が 残っていく。2、3 分後、モニター画面は 細い線で埋め尽くされ、まるで色とりどり の毛糸がからまった毛糸玉のようになる。

基本的に、このプログラムは八工を追 跡するものにすぎない。このアイデアは、 どの行動様式が興味深いものかを実験者 が判断できるようにする、沉用的な追跡お

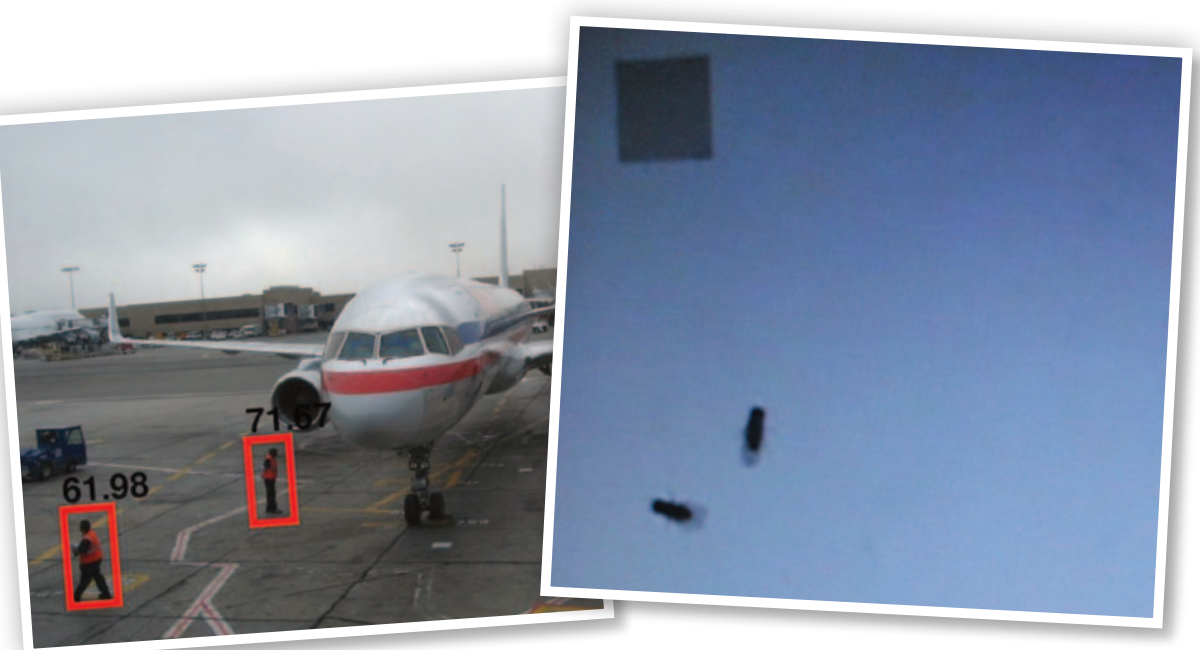

ハエの行動解析の自動化は、安全を脅かす潜在的リスクを察知する機械の開発につながるだろう。

よび定量化の機械装置を作製することだっ た。そしてその機械に、何を探しているか だけでなく、何を探すべなのかを学習する 方法も入力することだった。

「今は、研究の最も刺激的な側面の 1 つ、つまり発見段階に当たります」と Dickinson はいう。Pietroは、彼らが突 き止めた 1 つのおもしろい行動様式を説 明してくれた。「ゆっくり進む 1 匹の八工 がいて、もう 1 匹のハエがそれを追い越 しました」と彼が指でハエたちの動きを 真似しながら話した。「速いほうの八エが 遅いほうのハエを追い越すとき、遅いほ うのハエが止まりました。止まろうと決め たのは偶然なのかもしれません。しかし Michael（Dickinson）は実験をさらに進 め、まったく同じ例をもう 1 つ見つけたの です。その発見により、我々は同じような 経過をたどるハエどうしの出会いをすべて 抽出するソフトウエアのプログラムを、す ぐに作成できるのです」。研究者は直感だ けで、ハエのこうした行動様式には理由 があると考える、と Perona はいう。

しかし、実験者が、興味深い一連の動 きや相互作用をいったん見つけたなら、 仮説を立て、新しい解析によってそうした 仮説を裏付ける証拠を見つけることができ る。新しいデー夕は必要ではない。プロ グラムによって、ハエの個体ごとの各行動 様式が定量的に記述される。こうした「工 ソグラム (行動目録)」によって、研究者 は、例えば雌雄間や遺伝的变異をもつ八 工など、八工個体群間の行動様式のわず かな違いを見つけ出して定量化できる。し かも、1つの個体群内の個体差、いうな ればハエの「パーソナリティー」までもと らえることができる。

Dickinson の研究チームは既にこのエ ソグラムを使って、いくつかの新しい観察 結果を得ている。例えば雄バエは物怖じ せず、別のハエに歩み寄って検分し、時 には互いに小突き合うこともある。しかし、 雌は自分のパーソナル・スペースを必要と し、互いに出会ったときや歩き回るときに 
特定のエチケット・ルールに従う。

Dickinson の研究チームは、フィールド 内にコーンや障害物を置き、もつと複雑な 環境内では社会的なやりとりがどう変化す るかも調べ始めている。彼は、ハエがコー ンの頂上に登ろうとし、お互いにほかの 八エを追い払って「お山の大将」になり たがることに気付いた。こうした新しい観 察結果から、新たな仮説がいくつか導か れている。この行動は、食物供給源を見 つけ出すのに有利な場所を確保するため のものだ、とDickinson は話す。

そこから 2、300 メートル離れた実験室 では、Anderson が CADABRA (Caltech Automated Drosophila AggressionCourtship Behavioral Repertoire Analysis ; カルテック・ショウジョウバエ攻 撃一求愛レパートリー自動解析）という彼 のプログラムを使って、既に存在が知られ ている行動様式を定量的に観察している。 これらには、ハ工が攻撃を仕掛ける際に 試みるレスリングやタックル、その他もろ もろの技、交尾に至るまでの羽音による求 愛の「セレナーデ」やダンスなどがある。

彼は現在、あるスクリーニング法を開 発中で、既にさまざまな二ューロン集団を 遺伝学的に活性化したり抑制したりしてい る。こうした選択的機能破壊によって、各 行動の神経回路を細かく分析することがで きる。攻撃を 1 つのまとまりとしてだけで なく、この行動様式の各構成要素の頻度 や、1つの行動様式が別の行動様式につ ながる頻度も調べることができる。

彼の設定条件では、およそ 1 センチメー トルの高さで、大きさがゴルフボールの 直径ほどの 12 穴プレートのそれぞれの区 画に、ハエを 1 対入れる。上にカメラが 1 台吊るされ、12 の小部屋でのハエのや りとりを同時にすべて並行してフィルムに おさめる。その後、ビデオをコマごとに再 生して CADABRA にかけることで、すべて の行動様式の統計データが得られる。

CADABRA のエソグラムによって、例え ば飛びかかりと追い回しそれぞれの頻度
が明らかになる。加えて、追い回しの後に、 飛びかかる動作がくる頻度と、異性の気 を引こうとする羽の伸展動作がくる頻度が どれくらいあるのかなど、動作の移行頻 度も明らかになる。「これを 1 人の人間が 手動で行ったとすると、延べ 270 時間を 要します。でも我々はだいたい 20 分でやっ てしまいました」とAnderson はいう。

\section{「ファイト・クラブ」}

Levine は、自身と Dickinson が 2009 年 夏、ウッズホール海洋生物学研究所 (米 国マサチューセッツ州）で講義をしていた ときに、Ctraxについて学んだ。彼は今、 集団内の個々のハ工を、いっさいの妨害 なしに数日間にわたって追跡できるような システムを作っているところだ。

「集団での動態についてわかっているこ とは非常に少ないですね。どの個体がど の個体と相互作用するのか。一部の個体 の交尾回数が多いのはなぜか。社会的相 互作用は概日リズムにどのように影響し ているのか。これらは研究するのがとて も難しい分野でした。しかし今、Michael (Dickinson) と、この Ctrax というソフ トウエアを味方にできたことで、ついに疑 問の答えを出せます」。

ロックフェラー大学（米国ニューヨーク 州）の神経科学者 Leslie Vosshall は、求 愛行動の研究にCtrax を使っている。彼 女が使っているのは Dickinson の研究室 で設計された改良版で、ハエはプラスチッ ク製の蓋で覆われた円盤状のアリーナ内 をうろうろできるようになっている。この 改良版なら、ハ工は羽を切られずに動き 回ることができる。求愛行動には羽による シグナルや羽音を伴っているため、これは 極めて重要な改良点である。

また、Dickinson の下にいた大学院生 で、現在はハワード・ヒューズ医学研究所 ジャネリア・ファーム研究キャンパス（米 国バージニア州）にいる Michael Reiser は、Ctrax の融通のよさを利用して「ハ工 のオリンピック」を執り行っている。変異
バエに、歩行行動に対する視覚反射から 匂いの知覚まで、次々と行動テストをやら せているのだ。

Peronaは、自分の研究が生物学研究 で実を結び始めていることがうれしい、と 話す。また Anderson や Dickinson のプ ロジェクトによって、Perona が切望して いたラベル付けした行動ビデオ映像が得 られつつある。ハ工の行動様式をエソグ ラムにまとめることで、Perona には行動 の階層構造という自身の仮説を初めて検 証する機会ももたらされている。この仮 説によれば、求愛のように持続的で長い activity は複数の actionに分解され、そ れぞれの action はさらに、単純ではある が重要な意味をもつ motionに分解され るという。Peronaは、この概念が総合的 な行動コンピューテーショナル理論の土台 になってくれればと考えている。

ハエの行動が単純なおかげで、Perona は自分の概念を発展させることはできる。 しかし、今のところ彼ができるのはそこ までだ。「私は、ヒトが何をやっているか を把握できる機械の構築に近づいている のでしょうか。答えはイエスでもありノー でもあります。ハエはヒトよりも行動のレ パートリーがずっと単純で、無駄に時間を 費やすこともありません」。八工の行動を 詳しく観察することで、その仮説を検証す るもっと確かな方法を得て、ヒトのデータ に立ち戻ることができるはずである。しか し、Perona の目標は「進化」しつつある。 ハエの行動はやればやるほどおもしろさ が増してくると彼は話す。「すべてが解明 されて、私が生物学にいくらかの貢献が できていれば、いうことはありません」と 彼はいう。（船田晶子 訳）

Lizzie Buchen は、ワシントン DC に活動拠点を置 く Nature のインターン。

1. Dankert, H., Wang, L., Hoopfer, E. D., Anderson, D. J. \& Perona, P. Nature Meth. 6, 297-303 (2009).

2. Branson, K., Robie, A. A., Bender, J., Perona, P. \& Dickinson, M. H. Nature Meth. 6, 451-457 (2009).

3. Del Vecchio, D., Murray, R. M. \& Perona, P. Automatica 39 2085-2098 (2003) 